\title{
Phenolic Substances and Biological Activities of Verbana officinalis L.: A Mini-Review
}

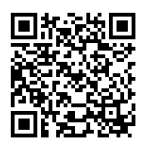

\author{
Hajer Riguene ${ }^{1}$, Ghayth Rigane ${ }^{1,2 *}$ and Ridha Ben Salem ${ }^{1}$ \\ ${ }^{1}$ Organic Chemistry Laboratory LR17ES08, Sciences of Sfax Faculty, Chemistry Department, University of Sfax, Tunisia
}

${ }^{2}$ Faculty of Sciences and Technology of Sidi Bouzid, Department of Physics \& Chemistry, University of Kairouan, Sidi Bouzid, Tunisia

Submission: January 15, 2019; Published: February 05, 2020

"Corresponding author: Ghayth Rigane, Organic Chemistry Laboratory LR17ES08, Sciences Faculty of Sfax, University of Sfax, Tunisia.

\begin{abstract}
The published data related to the identification of the major phenolic compounds as well as its biological activities present in Verbana officinalis L. This plant has received a great interest in the worldwide for its diuretic, expectorant and anti-rheumatic, anti-inflammatory, antifungal, antibacterial, analgesic and antioxidant activities.

Keywords: Verbana officinalis L; Phenolic substances; Biological activities
\end{abstract}

\section{Introduction}

Verbena officinalis or commonly referred as vervain belongs to the verbenaceae family (Table 1) which can be found in West Asia, North Africa and throughout Europe [1]. It is listed in the Chinese Pharmacopoeia and the British Herbal Pharmacopoeia [2]. Verbana is a medicinally used herb, where most people still depend on the folk medicine, despite the great progress in all opathic medicines, particularly to all eviateanxiety, insomnia, depression [3]. Verbena officinalis has been widely used for amenorrhea, insufficient lactation (lactogogue plant), assisting contractions duringlabor, promoting wound healing and for disorders of menstruation [4].

Table 1: Taxonomical Classification.

\begin{tabular}{|c|c|}
\hline Kingdom & Plantae \\
\hline Subkingdom & Tracheobionta - Vascular plants \\
\hline Super division & Spermatophyta - Seed plants \\
\hline Division & Magnoliophyta - Flowering plants \\
\hline Class & Magnoliopsida - Dicotyledons \\
\hline Sub class & Asteridae \\
\hline Order & Lamiales \\
\hline Family & Verbenaceae - Verbena family \\
\hline Genus & Verbena L. - vervain \\
\hline Species & Verbena officinalis L. \\
\hline
\end{tabular}

Botanical Characteristics

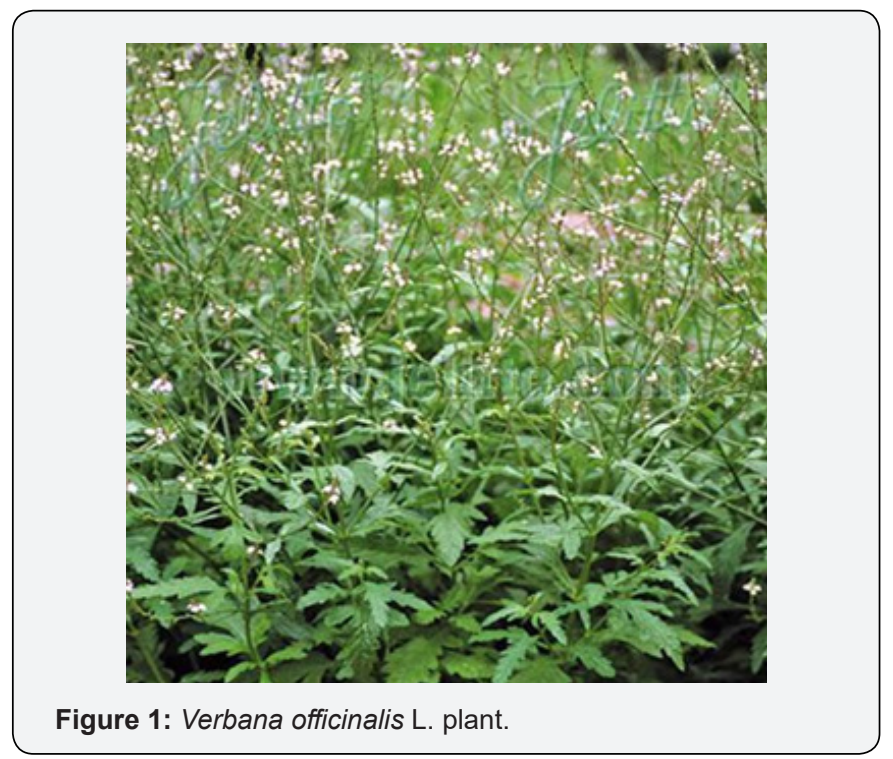

Verbena officinalis is a perennial herb. It is erect, 25-100 cm tall and branched above. Its leaves are $3.5-8 \mathrm{~cm}$ long and $1.5-3.5$ $\mathrm{cm}$ broad. It has pale pink or purplish color flowers about $4 \mathrm{~mm}$ across [5] (Figures 1 \& 2). 


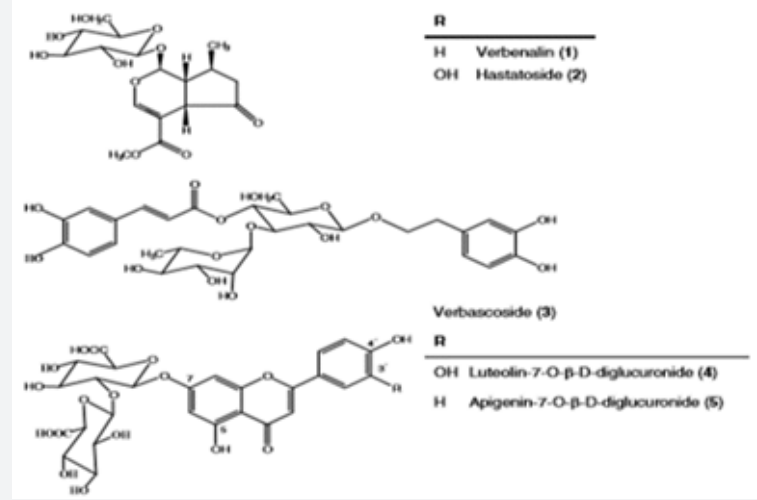

Figure 2: Chemical structure of some major constituents of Verbana officinalis.

\section{The Chemical Composition of Verbana officinalis}

Table 2: Phenolic compounds analysis techniques of Verbana officinalis L.

\begin{tabular}{|c|c|c|c|}
\hline $\begin{array}{l}\text { Phenolic Compounds } \\
\text { Analysis Techniques } \\
\text { of Verbana officinalis }\end{array}$ & Conditions & Major component & References \\
\hline \multirow{5}{*}{ LC-MS } & \multirow{5}{*}{$\begin{array}{c}\text { Gas temperature of } 350^{\circ} \mathrm{C} \text {, nitrogen flow rate of } 10 \mathrm{~L} \mathrm{~min}^{-1} \text {, nebulizer pres- } \\
\text { sure } 30 \text { psis, Quadrupole temperature } 30^{\circ} \mathrm{C} \text {, Capillary voltage } 3500 \mathrm{~V} \text {. The } \\
\text { applied fragmentors were in the range } 80-180 \mathrm{~V} \text {. }\end{array}$} & Verbenalin & \multirow{5}{*}[6]{} \\
\hline & & Hastatoside & \\
\hline & & Verbascoside & \\
\hline & & Isoverbascoside & \\
\hline & & Eukovoside or isomer & \\
\hline \multirow{5}{*}{$\begin{array}{l}\text { A micellar electroki- } \\
\text { netic capillary chroma- } \\
\text { tography: MECC }\end{array}$} & \multirow{5}{*}{$\begin{array}{c}\text { The compounds were detected either at } 205 \text { or } 235 \mathrm{~nm} \text {. Calibration data } \\
\text { confirmed linearity of the detector response within the concentration range } \\
\text { injected (R2 from } 0.997 \text { to } 0.999 \text { ), and revealed detection limits ranging from } \\
5.0 \mathrm{lg} \mathrm{mL} \text { ) } 1 \text { (verbascoside) to } 13.6 \mathrm{lg} \mathrm{mL} \text { ) } 1 \text { (hastatoside). The five markers } \\
\text { were readily }\end{array}$} & Verbenalin & \multirow{5}{*}[10]{} \\
\hline & & Hastatoside & \\
\hline & & Verbascoside & \\
\hline & & $\begin{array}{l}\text { Luteolin-7-0- } \beta \text {-D-diglucu- } \\
\text { ronide }\end{array}$ & \\
\hline & & $\begin{array}{l}\text { Apigenin-7-0- } \beta \text {-D-diglu- } \\
\text { curonide }\end{array}$ & \\
\hline \multirow{4}{*}{ LC-MS/MS } & \multirow{4}{*}{$\begin{array}{l}\text { UPLC separation was achieved using a Waters Acquity BHE C18 Column ( } 150 \\
3.9 \mathrm{~mm} \text { i.d. } 1.7 \mathrm{~mm} \text { particle size maintained at } 25^{\circ} \mathrm{C} \text { ), with a mobile phase } \\
\text { flow rate of } 0.4 \mathrm{~mL} / \mathrm{min} \text {. The mobile phase contained acetonitrile-ammonium } \\
\text { acetate } 5 \mathrm{mmol} / \mathrm{L} \text { (A) and water-ammonium acetate (B) in different propor- } \\
\text { tions. The elution system was : } 0-5 \mathrm{~min}, 93-90 \% \text { of B } ; 5-8 \mathrm{~min}, 90-80 \% \text { of B } \\
8-13 \mathrm{~min}, 80 \% \text { of B ; } 13-30 \mathrm{~min}, 80-40 \% \text { of B and } 30-40 \mathrm{~min}, 40 \% \text { of B. }\end{array}$} & Verbascoside & \multirow{4}{*}[8]{} \\
\hline & & Isoverbascoside & \\
\hline & & $\begin{array}{l}\text { campneoside II or b-hy- } \\
\text { droxyverbascoside }\end{array}$ & \\
\hline & & $\begin{array}{l}\text { isocampneoside II or b-hy- } \\
\text { droxy-isoverbascoside }\end{array}$ & \\
\hline \multirow{5}{*}{ UHPLC-DAD } & \multirow{5}{*}{$\begin{array}{c}\text { Capillary energy, } 3500 \mathrm{~V} \text {; nebulizer gas, } 34.8 \mathrm{psi} \text {; dry gas, } 10.0 \mathrm{~L} / \mathrm{min} \text { at a } \\
\text { temperature of } 280^{\circ} \mathrm{C} \text {; scan range, } \mathrm{m} / \mathrm{z} 100-1000 \text { with a scan rate of } 2 \mathrm{~Hz} \text {; } \\
\text { quadrupole, ion energy } 5 \mathrm{eV} \text {; low mass } \mathrm{m} / \mathrm{z} 300.00 \text {; collision cell, collision } \\
\text { energy } 10 \mathrm{eV} \text {; transfer time, } 60 \mu \mathrm{s} \text {; collision RF, } 266.7 \mathrm{Vpp} \text {; prepulsestorage, } \\
10 \mu \mathrm{s} \text {; transfer, funnel } 1 \mathrm{RF} 250.0 \mathrm{Vpp} \text {, funnel } 2 \mathrm{RF} 300.0 \mathrm{Vpp} \text {, hexapole RF } \\
454.8 \mathrm{Vpp} \text {. }\end{array}$} & Verbenalin & \multirow{5}{*}{ [9] } \\
\hline & & Luteolin 7-0-diglucuronide & \\
\hline & & Verbascoside & \\
\hline & & Luteolin 7-0-diglucuronide & \\
\hline & & $\begin{array}{c}\text { Apigenina } 7-0 \text {-diglucu- } \\
\text { ronide }\end{array}$ & \\
\hline
\end{tabular}

The main class of compounds of these plants were phenylpropanoids, being verbascoside the most abundant in all the preparations up to $97 \%$ of the total phenylpropanoids. In addition, iri- doids, has hastato side and verbenalin together with flavonoids, mono- and di-glucuronidic derivatives of luteolin and apigenin were found [6] (Table 2). 


\section{Organic and Medicinal Chemistry International Journal}

Several analytical techniques were used in order to identify and quantify the phenolic composition of Verbena officinalis, these techniques included high-performance liquid chromatography-mass spectrometry (LC-MS) [6,7], high-performance liquid chromatography-mass spectrometry/mass spectrometry LC-MS/
MS [8], ultra-high performance liquid chromatography diode array detector UHPLC-DAD [9], Micellar electro kinetic chromatography MECC [10] and High-performance liquid chromatography with diode-array detection HPLC-DAD [7] (Table 3).

Table 3: Screening of important essential oil isolated from Verbana officinalis $\mathrm{L}$.

\begin{tabular}{|c|c|c|c|}
\hline S.No & Name of compounds & Types & Article \\
\hline 1 & Hastatoside & Iridoid glucoside & [9] \\
\hline 2 & Verbenalin & Iridoid glucoside & [9] \\
\hline 3 & Luteolin 7-0-diglucuronide & Flavonoid & [9] \\
\hline 4 & Pedalitin 6-0-(2-0-feruloyl) -diglucuronide & Flavonoid & [7] \\
\hline 5 & Scutellarein 7-0-(2-0-feruloyl) -diglucuronide & Flavonoid & [7] \\
\hline 6 & Pedalitin 6-0-diglucuronide & Flavonoid & {$[7]$} \\
\hline 7 & Apigenin 7-0-diglucuronide & Flavonoid & [7] \\
\hline 8 & Aucubin & Iridoid & [7] \\
\hline 9 & Scutellarein 7-0-diglucuronide & Flavonoid & [7] \\
\hline 10 & 1,5-0-dicaffeoylquinic acid & Phenolic acid & [7] \\
\hline 11 & 4,5-0-dicaffeoylquinic acid & Phenolic acid & [7] \\
\hline 12 & Luteolin 7-0-glucuronide & Flavonoid & [7] \\
\hline 13 & Scutellarein 7-0-glucuronide & Flavonoid & [7] \\
\hline 14 & Luteolin 7-0-glucoside & Flavonoid & [7] \\
\hline 15 & Pedalitin 6-0-galactoside & Flavonoid & [7] \\
\hline 16 & Pedalitin 6-0-glucoside & Flavonoid & [7] \\
\hline 17 & Apigenin 7-0-galactoside & Flavonoid & [7] \\
\hline 18 & Apigenin 7-0-glucoside & Flavonoid & [7] \\
\hline 19 & Scutellarein 7-0-glucoside & Flavonoid & [7] \\
\hline 20 & Verbascoside & Phenolic acid & [9] \\
\hline 21 & Isoverbascoside & Phenolic acid & [8] \\
\hline 22 & Apigenin & Flavonoid & [7] \\
\hline 23 & Campneoside II & Phenylethanoid & {$[8]$} \\
\hline 24 & Isocampnenoide II & Phenylethanoid & [8] \\
\hline 25 & 4"'-acetyl-0-isoverbascoside & Phenylethanoid & [8] \\
\hline 26 & 2",4"-diacetyl-0-verbascoside & Phenylethanoid & [8] \\
\hline 27 & $3^{\prime \prime \prime}, 4^{\prime \prime \prime}$-diacetyl-0-isoverbascoside & Phenylethanoid & [8] \\
\hline 28 & $4^{\prime \prime \prime}, 6^{\prime \prime}$-diacetyl-0-betonyoside A & Phenylethanoid & [8] \\
\hline 29 & $3^{\prime \prime \prime}, 4^{\prime \prime \prime}$-diacetyl-0-betonyoside A & Phenylethanoid & [8] \\
\hline 30 & Betonyoside $\mathrm{A}$ & Phenylethanoid & [8] \\
\hline 31 & 6"-acetyl-0-isoverbascoside & Phenylethanoid & [8] \\
\hline 32 & $4^{\prime \prime \prime}$-O-acetyl-0-isoverbascoside & Phenylethanoid & [8] \\
\hline
\end{tabular}

\section{The Biological Activities of Verbana officinalis}

The famous properties of vervain herb are sedative, antispasmodic and diaphoretic [11]. Verbena officinalis L. has been traditionally used as nervine tonic, antidepressant, and anticonvulsant; prescribed in liver and gall bladder complaints (spasm of the bladder and strangury), nervous and menstrual disorders; also, for bronchitis, asthma and febrile affections [12].
In addition to that, Verbana officinalis can be utilized to treat enteritis, acute dysentery, depression and amenorrhea [13]. The scavenging activity against DPPH (1,1diphenil-2-picrylhydrazyl) radical and the antifungal effect against chloroform, ethylacetate and $50 \%$ methanolic extracts of Verbena officinalis leaves were investigated. The activity of different fractions of $50 \%$ methanolic extract and some isolated compounds were also investigated. The 
results suggest that $50 \%$ methanolic extract and caffeoyl derivatives could potentially be considered as excellent and readily available sources of natural antifungal and antioxidant compounds [2].

The antimicrobial potential of verbana herb leaves, and roots was evaluated against 24 strains of Gram-positive and Gram-negative bacteria by Dildar [5]. Ethanolic extracts of stems, leaves, and roots of Verbena officinalis and their fractions in various solvents were assessed. The stems proved to be most potent against all the strains. Its activity against Staphylococcus aureus and Pseudomonas aeruginos a was higher than the antibiotic Amoxicillin.

The leaves also showed considerable activity against Pseudomonas aeruginosa, Citrobacter freundii, and Staphylococcus aureus. The roots turned out to be highly effective against Bacillus subtilis, Staphylococcus aureus, and Pseudomonas aeruginosa The study confirmed the efficacy of Verbena officinalis against infectious diseases. While all the three parts of the plant were active against the test micro-organisms, stems were most powerful. The plant has great potential to provide exploitable leads for new antimicrobial drugs [5].

\section{Conclusion}

The biological activities of Verbana officinalis L., including antioxidant, anti-microbial, anti-inflammatory and anti-cancer, were due to the presence of bio-active compounds in the leaves such as: Verbenalin, Hastatoside, Verbascoside, Luteolin-7-0- $\beta$-D-diglucuronide, Apigenin-7-O- $\beta$-D-diglucuronide.

\section{References}

1. Abebe M, Abebe A, Mekonnen A (2017) Assessment of antioxidant and antibacterial activities of crude extracts of verbena officinalis Linn root or Atuch (Amharic). Chem Int 3: 172-184.s

2. Casanova E, García Mina JM, Calvo MI (2008) Antioxidant and Antifungal Activity of Verbena officinalis L. Leaves. Plant Foods Hum Nutr 63: 93-97.
3. Abdulmannan HF, Zahurin M, Zamri C, Abdulsamad A, Siti RMZ, et al. (2019) Prenatal developmental toxicity evaluation of Verbena officinalis during gestation period in female Sprague-Dawley rats. Chem Biol Interact 304:28-42.

4. Abdulmannan HF, Zahurin M, Zamri C, Abdulsamad A, Siti RMZ, et al. (2019) Mutagenicity and genotoxicity effects of Verbena of icinalis leaves extract in Sprague-Dawley Rats. J Ethnopharmacol 235: 88-99.

5. Dildar A, Kamal AQ, Chaudhary MA, Husnul M (2017) Verbena officinalis a herb with promising broad spectrum antimicrobial potential. J Med Chem 3(1).

6. Bilia AR, Giomi M, Innocenti M, Gallori S, Vincieri FF (2008) HPLCDAD-ESI-MS analysis of the constituents of aqueous preparations of verbena and lemon verbena and evaluation of the antioxidant activity. J Pharm Biomed Anal 46: 463-470.

7. Rehecho S, Hidalgo O, Cirano MGI, Navarro I, et al. (2011) Chemical composition, mineral content and antioxidant activity of Verbena officinalis L. LWT - Food Sci Technol 44: 875-882.

8. Encalada MA, Rehecho S, Ansorena D, Astiasaran I, Cavero RY, et al. (2015) Antiproliferative effect of phenylethanoid glycosides from Verbena officinalis L. on Colon Cancer Cell Lines. LWT - Food Sci Technol 63: 1016-1022.

9. Eisath NG, Eichberger M, Gruber R, Sturm S, Stuppner H (2018) Development and validation of a rapid ultra-high-performance liquid chromatography diode array detector method for Verbena officinalis L. J Pharm Biomed Anal.

10. Müller A, Ganzera M, Stuppner H (2004) Analysis of the aerial parts of verbana officinalis L. by micellar electrokinetic capillary chromatography. Chromatographia 60: 193-197.

11. Kubica P, Szopa A, Ekiert H (2017) Production of verbascoside and phenolic acids in biomass of Verbena officinalis L. (vervain) cultured under different in vitro conditions. Nat Prod Res 31(14):1663-1668.

12. Kumar P, Madaan R, Sidhu S (2017) Antianxiety Activity of Fractions and Isolated Compounds of Verbena officinalis Aerial Parts. Int j pharm sci drug res 9: 79-82.

13. Sumaira, Afridi MS, Hashmi SS, Ali GS, Zia M, et al. (2018) Comparative antileishmanial efficacy of the biosynthesised ZnO NPs from genus Verbena. IET Nanobiotechnol 12(8): 1067-1073.

\section{Your next submission with Juniper Publishers will reach you the below assets}

- Quality Editorial service

- Swift Peer Review

- Reprints availability

- E-prints Service

- Manuscript Podcast for convenient understanding

- Global attainment for your research

- Manuscript accessibility in different formats

(Pdf, E-pub, Full Text, Audio)

- Unceasing customer service

\section{Track the below URL for one-step submission}

https://juniperpublishers.com/online-submission.php 